\title{
Terrorismo mediático: incidencia del tratamiento mediático en la imagen del menor pandillero en Honduras
}

Media Terrorism: Incidence of Media Treatment on the Image of Minor Gang Members in Honduras

\section{Yaritza María VÁsquez HeRnández \\ Universidad de Granada ymvasquez@correo.ugr.es}

Resumen: La actual construcción social del miedo se constituye como una realidad emergente que forma parte de la vida diaria de los hondureños. Y es que, la delincuencia juvenil presente a través de la participación del menor en sus actividades criminales, no solo suscita una sensación de inseguridad que es recrudecida por el tratamiento mediático, sino también demanda la implementación de medidas más represivas sobre el accionar criminal de los menores. El objetivo de este artículo radica en el análisis del tratamiento mediático, y cómo influye en la percepción social sobre los menores mareros; para ello, se parte de una revisión documental, en el que se analiza de manera descriptiva e interpretativa los aspectos vinculantes a la opinión pública que generan los medios de comunicación social, sobre el que se manifiesta un discurso sensacionalista con un efecto estigmatizador sobre los menores que residen en las

VÁsquez Hernández, Yaritza María (2021). «Terrorismo mediático: incidencia del tratamiento mediático en la imagen del menor pandillero en Honduras». Monograma. Revista Iberoamericana de Cultura y Pensamiento, n. ${ }^{\circ}$ 8, pp. 181-206. doi: 10.36008/monograma.2021.08.2146. http: revistamonograma.com. ISSN: 2603-5839. 
zonas marginadas controladas por las maras. La búsqueda y el análisis de la información sistematizada sugiere que los medios de comunicación refuerzan la imagen de menor delincuente, así como la intromisión del fenómeno de la posverdad, comprendida como una realidad distorsionada que provoca reproche social. En definitiva, los resultados encontrados sugieren que los medios de comunicación se comportan como un generador de opinión pública con un matiz estigmatizador sobre los menores que conforman las maras.

Palabras clave: menores, maras, medios de comunicación social, tratamiento mediático.

Abstract: The current social construction of fear is constituted as an emerging reality that is part of the daily life of the Hondurans. And it is that, juvenile delinquency present through the participation of the child in his criminal activities, not only does it arouse a sense of insecurity that is restined by media treatment, but also demands the implementation of more repressive measures on the criminal action of child offender. The objective of this article lies in the analysis of media treatment, and how it influences social perception about child in the gangs; for this purpose, it is based on a documentary review, which discusses in a descriptive and interpretative way the aspects binding on the public hearing generated by social media, on which a sensationalist discourse is manifested with a stigmatizing effect children residing in marginalized areas controlled by the maras. The search and analysis of systematized information suggests that the media reinforces the image of a juvenile offender, as well as the intrusion of the phenomenon of post-truth, understood as a distorted reality that provoques social reproach. Definitely the results found suggest that the media behaves like a generator

VÁsquez Hernández, Yaritza María (2021). «Terrorismo mediático: incidencia del tratamiento mediático en la imagen del menor pandillero en Honduras». Monograma. Revista Iberoamericana de Cultura y Pensamiento, n. ${ }^{\circ}$ 8, pp. 181-206. doi: 10.36008/monograma.2021.08.2146. http: revistamonograma.com. ISSN: 2603-5839. 
of public opinion with a stigmatizing nuance about the child gang members.

Keywords: child, gangs, social media, media treatment.

Fecha de recepción: $27 / 7 / 2020$

Fecha de aceptación: 17/2/2021

VÁsquez Hernández, Yaritza María (2021). «Terrorismo mediático: incidencia del tratamiento mediático en la imagen del menor pandillero en Honduras». Monograma. Revista Iberoamericana de Cultura y Pensamiento, n. ${ }^{\circ}$, pp. 181-206. doi: 10.36008/monograma.2021.08.2146. http: revistamonograma.com. ISSN: 2603-5839. 



\section{Introducción}

La actual sociedad se enfrenta ante una era globalizada, en la que el uso de las tecnologías de información y comunicación (TIC) se convierte en un instrumento fundamental no solo para estar socialmente conectados, sino para comprender el mundo en el que vivimos. Sobre ese prisma, los medios de comunicación social (MCS) ocupan un papel relevante para determinar los acontecimientos que suceden a nuestro alrededor de manera local, nacional y transnacional. Sin embargo, como parte de los efectos colaterales, los MCS inciden en la formación de opiniones públicas, las cuales fomentan la percepción social que tiene la ciudadanía sobre determinados fenómenos sociocriminales.

El recrudecimiento de la violencia y delincuencia se hace latente en la construcción social del miedo que se ha instaurado en Honduras, y que se exacerba aun más en la participación del menor en el accionar criminal de las maras. Dicha construcción compele a diferentes contextos, tanto a la experiencia que haya podido padecer un individuo como víctima directa, a relatos de terceros cercanos a su entorno, pero principalmente al tratamiento mediático que se convierte en la principal fuente de información social (Navarro, 2005: 78).

Bajo esta atmósfera social, se puede visualizar como los MCS agudizan el imaginario social sobre el fenómeno criminal de las maras; deformando la realidad de sus actos y remitiéndola a escenarios revestidos de actos satánicos, tal como

VÁsquez Hernández, Yaritza María (2021). «Terrorismo mediático: incidencia del tratamiento mediático en la imagen del menor pandillero en Honduras». Monograma. Revista Iberoamericana de Cultura y Pensamiento, n. ${ }^{\circ}$ 8, pp. 181-206. doi: 10.36008/monograma.2021.08.2146. http: revistamonograma.com. ISSN: 2603-5839. 
aseguraba una nota publicada en el Washington Post, en la que la Mara Salvatrucha llevaba a cabo supuestos ritos satánicos como parte de la identidad colectiva de esa organización (Mendoza, 2017).

Desde otro ángulo, la falta de información sobre la problemática real que afecta a los menores y jóvenes que participan dentro del mundo criminal de las maras, incita a que la sociedad sobredimensione este fenómeno como una secta satánica en la que cuyos miembros están alejados de todo sentir y valor social. Es precisamente sobre esta consideración recae el temor social se ha propagado, encendiendo las alarmas que aumenta la percepción de inseguridad y sitúa al contexto geográfico de Honduras como uno de los países más violentos del mundo sin mediar conflicto de guerra.

Por otra parte, la falta de conocimiento sobre la problemática real de los menores y jóvenes que se inmiscuyen en el mundo criminal de las maras, provoca que la ciudadanía sobreestime este fenómeno como una secta, propagándose el temor social sobre el que se ha construido la idea de inseguridad. ${ }^{1}$

Esta imagen distorsionada que segregan los MCS sobre la participación de las maras en actos más sanguinarios y violentos, repercute en la presión social de la ciudadanía sobre la entidad estatal para controlar el fenómeno. Se aboga, por tanto, en una intervención más represiva hacia los menores mareros y pandilleros, conducente al endurecimiento de las medidas que se

1 Una nota emitida por un medio de comunicación de Washington, hace referencia a los supuestos ritos satánicos llevados a cabo por miembros de la Mara Salvatrucha como parte de sus actividades dentro de la organización. Para más información véase la siguiente nota: https:// www.laprensagrafica.com/elsalvador/La-MS-13-le-entrega-almas-al-diablo-el-trasfondosatanico-de-esta-pandilla-segun-The-Washington-Post-20171227-0057.html.

VÁsquez Hernández, Yaritza María (2021). «Terrorismo mediático: incidencia del tratamiento mediático en la imagen del menor pandillero en Honduras». Monograma. Revista Iberoamericana de Cultura y Pensamiento, n. ${ }^{\circ}$ 8, pp. 181-206. doi: 10.36008/monograma.2021.08.2146. http: revistamonograma.com. ISSN: 2603-5839. 
deben adoptar en los Centros de Menores, así como la proposición de reducir la edad punible.

Asimismo, esa masiva reproducción de notas, ha supuesto la estigmatización social sobre ellos por proceder de ambientes marginados y conflictivos, condenándoles por haber crecido en un entorno que los empujó hacia su carrera criminal (Maza y Alonso, 2017: 36).

Este sello delincuencial que se marca sobre ellos, permite una mayor vulnerabilidad frente a los procesos de integración y participación criminal de los menores en las maras y pandillas, como respuesta a una sociedad que los rechaza, un Estado que ignora sus carencias socioeconómicas, y una familia que desatiende sus carencias afectivas.

Por otra parte, el tratamiento mediático alimenta el discurso político de medidas de «mano dura» o «cero tolerancia» sobre los miembros de las maras, que se concretan a través de mecanismos represivos como la creación de la «Fuerza Nacional Anti Maras y Pandillas», lo que no solo ha provocado una postura de rechazo social hacia los menores, sino también toda omisión a procesos de inclusión social como alternativa y control a su actividad criminal en las maras.

Ciertamente los MCS juegan un papel clave como agente social; sin embargo, su rol ha estado encaminado a un tipo de terrorismo mediático, que genera una continua producción de imágenes violentas que propicia una opinión pública, que evoca en una sensación de continuo riesgo y una percepción de inseguridad latente ante la perpetración de delitos por parte de las maras y pandillas (Brandariz García, 2007: 73).

VÁsquez Hernández, Yaritza María (2021). «Terrorismo mediático: incidencia del tratamiento mediático en la imagen del menor pandillero en Honduras». Monograma. Revista Iberoamericana de Cultura y Pensamiento, n. ${ }^{\circ}$ 8, pp. 181-206. doi: 10.36008/monograma.2021.08.2146. http: revistamonograma.com. ISSN: 2603-5839. 
2. Ámbitos de estudios

\subsection{Proximidad a la noción de menores, delincuencia juvenil, maras y terrorismo mediático}

En este primer apartado se abordan cuestiones terminológicas vinculantes a la comprensión del tratamiento mediático sobre la participación del menor en las maras y pandillas.

\subsubsection{Concepto de menor (niño, niña y adolescente)}

El acogimiento del término niño se encuentra enmarcado en diferentes instrumentos internacionales, lo cual permite una mayor comprensión sobre su caracterización. En la Convención sobre los Derechos del Niño se considera en su artículo 1 que el término «niño» hace referencia «a todo ser humano menor de 18 años, salvo, que en virtud de la ley que le sea aplicable, haya alcanzado antes la mayoría de edad».

Ante el debate que pueda generar este artículo, el Comité de los Derechos del Niño considera que solo se permitirá fijar la mayoría de edad a una edad menor en los casos que no se menoscabe ninguno de los derechos tutelados en la Convención.

Por otra parte, y como producto de la ratificación al anterior instrumento en mención, el Código de la Niñez y Adolescencia en Honduras estipula para todos los efectos legales, que «niño es todo individuo menor de 18 años»; asimismo, hace explícita mención de que la niñez se comprende en los siguientes periodos: «La infancia que comienza con el nacimiento y finaliza hasta los (12) años en los varones, y hasta los (14) años en las niñas. La adolescencia se fija desde las edades antes mencionadas hasta alcanzar los 18 años».

En este mismo sentido, el término adolescente tiene por finalidad diferenciar entre franjas etarias para poder reconocer el

VÁsquez Hernández, Yaritza María (2021). «Terrorismo mediático: incidencia del tratamiento mediático en la imagen del menor pandillero en Honduras». Monograma. Revista Iberoamericana de Cultura y Pensamiento, n. ${ }^{\circ}$ 8, pp. 181-206. doi: 10.36008/monograma.2021.08.2146. http: revistamonograma.com. ISSN: 2603-5839. 
progreso del individuo en su capacidad de autonomía; por lo que el reconocimiento de derechos y obligaciones diferenciados surge a partir del desarrollo de sus habilidades. Es imprescindible que dicha distinción se origina sobre la capacidad de los adolescentes para tomar ciertas decisiones, aunque a un grado limitado de comprensión y consciencia. Esta argumentación para diferenciar la franja entre la niñez y adolescencia se deriva del sistema de justicia juvenil, en el cual está destinado únicamente a los adolescentes, es decir las personas mayores de 12 años, pero menores de 18 años; reconociendo que los niños menores de doce años son inimputables, conforme se cita en el Código Penal de Honduras en el artículo 22, en las causas eximentes de responsabilidad penal (Contró, 2011: 37).

De manera más concreta, en el campo del derecho cuando se hace referencia al concepto de menores, se estudia la capacidad del adolescente que habiendo infringido las leyes penales queda sometido bajo una ley especial, para ser procesado y juzgado conforme a los principios del sistema de justicia de menores.

\subsubsection{Delincuencia juvenil y maras}

Sin perjuicio del objeto de estudio, es relevante aproximarnos al concepto de la delincuencia juvenil, cómo una realidad sociocriminal sobre la que se manifiesta la participación del menor en las maras. La caracterización de la sociedad globalizada actual genera graves consecuencias en diversos ámbitos de la realidad social; uno de ellos «la delincuencia», con un alcance que responde al surgimiento de diversos factores. La delincuencia constituye un fenómeno social que se conforma por un cúmulo de acciones contradictorias a las normas fundamentales de convivencia, las cuales se ejecutan en un tiempo y espacio determinado (Herrero Herrero, 2017: 267).

VÁsquez Hernández, Yaritza María (2021). «Terrorismo mediático: incidencia del tratamiento mediático en la imagen del menor pandillero en Honduras». Monograma. Revista Iberoamericana de Cultura y Pensamiento, n. ${ }^{\circ}$ 8, pp. 181-206. doi: 10.36008/monograma.2021.08.2146. http: revistamonograma.com. ISSN: 2603-5839. 
Sin embargo, este concepto no delimita la intromisión de la figura delincuencial, por lo que se atiende al concepto de delincuente juvenil como una figura cultural que responde a diversos factores que le condicionan a delinquir, según su región y contexto; manifestando una mezcla de elementos psicológicos y legales que complementan el perfil del delincuente juvenil. Por lo que un «delincuente juvenil o menor infracton», sería toda persona menor de 18 años que no tiene edad penal para responder y que comete un hecho tipificado como delito en la ley (Genovés, 1986: 11).

Uno de esos fenómenos sociocriminales sobre los cuales se refleja el alcance de la delincuencia juvenil, se encuentra en las maras $^{2}$. Desde la comprensión del autor Pedro Gallego (2009) estas constituyen una pandilla juvenil la cual se caracteriza por el alcance de su violencia. Son agrupaciones de jóvenes, compuestas por hombres y mujeres, entre edades comprendidas de 5 a 35 años, y que se suelen asociar con la finalidad de controlar el territorio de determinadas zonas. Su estilo de vida se ve consolidado con el sentimiento de pertenencia, misma que los lleva a perpetrar cualquier acto ilícito, ordenado por los miembros; pudiendo incluso perder la vida en la ejecución de sus actividades.

Cabe señalar, que desde la consideración de algunos autores las maras se pueden considerar como una secta con finalidades destructivas, debido a que a sus criterios cumplen con las características que definen a las sectas: 1) El uso de técnicas coercitivas para persuadir en su captación o adoctrinamiento a los miembros que van a ingresar, destruyendo su antigua personalidad para consolidar la identidad grupal de las maras; 2) El reem-

\footnotetext{
2 Las maras se han considerado como una amenaza a la seguridad no solo del área urbana de las ciudades, su expansión comienza a proliferar en zonas rurales y puntos estratégicos desde alrededor de toda Honduras, incluso representan una amenaza internacional con precedentes en los países de España. Véase: https://www.elmundo.es/elmundo/2009/09/04/ internacional $/ 1252031869 . \mathrm{html}$.
}

VÁsquez Hernández, Yaritza María (2021). «Terrorismo mediático: incidencia del tratamiento mediático en la imagen del menor pandillero en Honduras». Monograma. Revista Iberoamericana de Cultura y Pensamiento, n. ${ }^{\circ}$ 8, pp. 181-206. doi: 10.36008/monograma.2021.08.2146. http: revistamonograma.com. ISSN: 2603-5839. 
plazo de familia, a través de la destrucción total o parcial de los vínculos afectivos y comunicativos con su familiares y amigos, o bien dejar atrás su yo (personalidad) y su entorno social como parte del proceso de integración a las maras; 3) Violación o conculcación de los derechos jurídicos inalienables a un Estado de Derecho (Rodríguez, 1985: 45).

No obstante, para efectos del presente artículo, utilizaremos el concepto de maras enfocado a una organización criminal transnacional; que está conformada por menores, jóvenes y adultos, cuyas edades oscilan entre los 12 y 35 años de edad. Los cuales se dedican a realizar actividades de origen ilícito (secuestro, sicariato, extorsión, narcotráfico) por lo que suelen rivalizar de manera constante con sus coetáneos, por la lucha del control territorial de determinadas zonas donde ejercen la violencia como un estilo de vida.

\subsection{3. ¿Tratamiento mediático o terrorismo mediático?}

La definición sobre terrorismo mediático aún no se encuentra consolidada; mientras algunos hablan sobre difusión del miedo, otros hablan de infringir terror sobre verdades distorsionadas. Sin embargo, si hay algo que podemos añadir es la vinculación entre el fenómeno de la posverdad y lo denominado terrorismo mediático; y es el asesinato del periodismo objetivo, siendo sustituido por la propaganda y el sensacionalismo, renaciendo en la especulación (Fernández, 2008: 255).

En los medios de comunicación social, de manera especial en los audiovisuales la visualización de una imagen con un fuerte contenido suele contrarrestar la racionalidad para ceder paso al terreno de las emociones, generando un estereotipo sobre un grupo. Por lo que la continua exposición de hechos con carácter

VÁsquez Hernández, Yaritza María (2021). «Terrorismo mediático: incidencia del tratamiento mediático en la imagen del menor pandillero en Honduras». Monograma. Revista Iberoamericana de Cultura y Pensamiento, n. ${ }^{\circ}$ 8, pp. 181-206. doi: 10.36008/monograma.2021.08.2146. http: revistamonograma.com. ISSN: 2603-5839. 
negativo sobre determinado grupo conlleva al grave riesgo de estereotipación, la cual suele estar sobreestimada.

En ese sentido, una perspectiva desde el periodismo que enmarque desmesuradamente las distinciones o acciones puede propiciar la incomprensión hacia ciertos grupos, empujando dicha situación a un riesgo de discriminación y exclusión social (Maz, 2010: 88).

Sin duda alguna, la sensación de inseguridad es un hecho que se ha asumido como parte del diario vivir en la mayoría de los países de América Latina, pero de manera especial en los países del triángulo norte (Honduras, Guatemala y El Salvador). La mayoría de hechos criminales es conocido a través de los medios de comunicación, quienes contribuyen a generar imaginarios sociales; y es que la mayor parte de los medios emiten información relacionada a la seguridad ciudadana que incide hondamente en la construcción de una sensación de inseguridad, sobre el temor de convertirse en víctima de algún delito.

El debate que se origina entorno al tratamiento mediático del delito, no se trata del número de noticias vinculadas al tema de seguridad, sino a que la cobertura presta especial énfasis a la situación de riesgo a la que se encuentra expuesta la población, lo que adquiere un papel protagónico en los medios de difusión como parte de un espectáculo que convierte a la difusión de la violencia en un negocio. Evidentemente los MCS encuentran en las noticias violentas y delictivas de los menores en las maras, una especie de cuento mediático con efecto sensacionalista que logra infiltrarse en el imaginario colectivo e incide intensamente en la percepción social. Esa sensación de inseguridad que se recrea a través de la masiva producción de imágenes violentas y hechos delictivos contiene un componente subjetivo de suma

VÁsquez HernÁNdez, Yaritza María (2021). «Terrorismo mediático: incidencia del tratamiento mediático en la imagen del menor pandillero en Honduras». Monograma. Revista Iberoamericana de Cultura y Pensamiento, n. ${ }^{\circ}$ 8, pp. 181-206. doi: 10.36008/monograma.2021.08.2146. http: revistamonograma.com. ISSN: 2603-5839. 
importancia, el cual se apoya en apreciaciones distorsionadas o sobredimensionadas (Fazio, 2013: 126).

Vinculado al concepto de sensación de inseguridad, conviene comprender que el miedo a la delincuencia deviene del margen de probabilidad que tiene cada individuo de convertirse en víctima de un delito, por lo que su percepción se enfoca más al plano emocional, que al racional (Navarro, 2005: 78). Lo que supone que el refuerzo de la noción «miedo al delito» compele a su vez a la teoría de la construcción social de la realidad, en la que se sostiene que no se puede discutir para el caso que nos atañe, que la delincuencia, el delito o la violencia son fenómenos reales, pero a su vez una construcción social; dicho de otra forma la sociedad construye un fenómeno social a la medida que le da mayor importancia (Luckmann y Berger Thomas, 1968: 11).

Simultáneamente, todas estas observaciones guardan una estrecha relación con los discursos mediáticos sobre la participación criminal del menor en las maras, en los que el sensacionalismo, la represión y el miedo contribuyen a reducir de manera gradual la confianza que el colectivo social tiene en sus autoridades gubernamentales. De ahí, que la aseveración sobre la pérdida de confianza pueda ser aprovechada para generar una especie de cuento mediático; en la que dicha desconfianza en el Gobierno pueda generar un imaginario de alteración al orden social y por lo tanto reclama accionar con «mano dura», priorizando políticas represivas $^{3}$ y populistas de corto plazo; frente a soluciones más responsables. A ello se debe añadir, además, que el sensacionalismo y alarmismo contribuyen a promover no solo la desin-

3 El Gobierno de Honduras crea la institución «Fuerza Nacional Anti Maras y Pandillas» cómo un mecanismo de control social para erradicar la problemática criminal. Para más información, véase la siguiente nota periodística: https://hondudiario.com/2018/05/07/crean-fuerza-nacional-antimaras-y-pandillas/

VÁsquez Hernández, Yaritza María (2021). «Terrorismo mediático: incidencia del tratamiento mediático en la imagen del menor pandillero en Honduras». Monograma. Revista Iberoamericana de Cultura y Pensamiento, n. ${ }^{\circ}$ 8, pp. 181-206. doi: 10.36008/monograma.2021.08.2146. http: revistamonograma.com. ISSN: 2603-5839. 
tegración familiar, sino que refuerzan la agresión, y con ello la violencia y la delincuencia (Huhn, 2008: 162).

2.2. Una mirada teórica a la teoría del etiquetaje, y su conexión con la participación del menor en las maras a través del tratamiento mediático

Nuestra naturaleza humana se suele regir por estereotipos; es decir, por pensamientos asumidos y aceptados socialmente que se encuentran basados en etiquetas impuestas por lo medios de comunicación, de manera inconsciente. Ante eso atendemos a un breve repaso hacia la teoría labelling approach o también denominada «teoría de la reacción social» o «el etiquetamiento». La cual vino a otorgar un papel relevante a los grupos sociales como los forjadores de la conducta criminal, al confeccionar normas cuya contravención constituye una desviación; así como la aplicabilidad de dichas normas a los sujetos mediante el etiquetaje como desviados o delincuentes (Herrero, 2017). En este sentido, no se puede apelar a la comprensión del crimen sin atender a la reacción social, en la cual se lleva a cabo un proceso de selección social sobre ciertas personas, y conductas que son etiquetadas como criminales. Cada una de esas etiquetas encuentra su función en la construcción social, pudiendo generarse a raíz de la opinión pública que se genere tras una noticia (Gonzáles y Calderón, 2013: 118).

Dentro de los principales postulados que encontramos en esta teoría y que conducen a la comprensión de la conducta criminal del delincuente, se establecen los siguientes:

1. La implicación del interaccionismo simbólico y del constructivismo social: la interacción es parte de nuestra naturaleza como seres humanos, sobre la cual vamos construyendo definiciones y dando significado conforme se produce nues-

VÁsquez Hernández, Yaritza María (2021). «Terrorismo mediático: incidencia del tratamiento mediático en la imagen del menor pandillero en Honduras». Monograma. Revista Iberoamericana de Cultura y Pensamiento, n. ${ }^{\circ}$ 8, pp. 181-206. doi: 10.36008/monograma.2021.08.2146. http: revistamonograma.com. ISSN: 2603-5839. 
tra realidad social. Dentro de este postulado es fundamental para comprender la conducta criminal, conocer la imagen que tiene la persona sobre sí mismo, sobre su entorno social próximo y que lugar ocupa dentro de este contexto.

2. Una mirada empática hacia la construcción identitaria del desviado, afín de aproximarse hacia la realidad criminal desde el punto de vista del delincuente y el sentido que le atribuye a su conducta.

3. Una conducta no es delictiva por sí misma, sino por el significado o definición que adquiere, conforme los procesos sociales que seleccionan etiquetas del autor de la conducta como delincuente.

4. Los sistemas de control social forjan la criminalidad al etiquetarla.

5. Los sistemas de control social son hondamente discriminatorios y selectivos, la calificación que adquiere un individuo como delincuente adquiere su valor no en la acción realizada, sino en la posición social que este ocupa en su entorno.

6. La pena o el internamiento de los menores en centros agrava la imagen de degradación del condenado, repercutiendo en la asimilación de una nueva imagen que redelimita su personalidad en atención al rol desviado, que se conoce como desviación secundaria.

7. Los procesos de criminalización sobre el individuo, sobre las que se le atribuye un etiquetamiento criminal. (Gonzáles y Calderón, 2013: 118)

El enfoque de la teoría de etiquetamiento se centra, por tanto, que una vez que el individuo transita en la desviación primaria, es decir en el incumplimiento o violación de las normas de una colectividad, a causa por ejemplo de un estado de necesidad, su conducta no es percibida de manera negativa por el individuo.

VÁsquez Hernández, Yaritza María (2021). «Terrorismo mediático: incidencia del tratamiento mediático en la imagen del menor pandillero en Honduras». Monograma. Revista Iberoamericana de Cultura y Pensamiento, n. ${ }^{\circ}$ 8, pp. 181-206. doi: 10.36008/monograma.2021.08.2146. http: revistamonograma.com. ISSN: 2603-5839. 
Sin embargo, en este proceso confluye un proceso de estigmatización por parte de los agentes sociales, en el que el efecto de los medios de comunicación desempeña un papel fundamental en la opinión del colectivo, provocando una reacción social estigmatizadora sobre el individuo que cometió un hecho delictivo sin ser consciente de ello, pero que provocan una etiqueta de delincuente; un señalamiento aversivo. Al escudriñar los efectos de esta Teoría del etiquetaje, sugiere que el individuo asumirá lo señalado por su entorno, llevándole a reinventar el autoconcepto que tiene de sí mismo como delincuente, siendo más propenso a la ejecución de actos delictivos al acogerlo en un contexto subcultural.

Los hilos de esta teoría señalan, que una vez que el individuo adopta el estatus de delincuente es muy complicado cambiar su autopercepción: debido al conflicto social que se genera en la comunidad al reinsertar a su entorno al individuo etiquetado; y, por otra parte, porque los señalamientos y la difusión sobre estos mismos tiene un efecto de interiorización, sobre el cual la autoimagen del sujeto es percibida en base a etiquetas. Con ello, se debe resaltar que los efectos sobre los que recae este proceso de estigmatización se convierten en una condena pública que obliga a la exclusión del individuo; dificultando no solo su rehabilitación e inserción social, sino empujándole al recrudecimiento de actos delictivos. Asimismo, el etiquetaje del individuo lo sella de tal modo que se pronostica desde su entorno social una trayectoria delincuencial más potente a futuro (Gonzáles y Calderón, 2013: 119).

Extrapolando dicha teoría a la participación del menor en las maras, se dimensiona que los procesos de criminalidad selectiva como ocurre en el marco de la teoría de etiquetaje, aluden al desarrollo de la estigmatización sobre dos representaciones: en

VÁsquez Hernández, Yaritza María (2021). «Terrorismo mediático: incidencia del tratamiento mediático en la imagen del menor pandillero en Honduras». Monograma. Revista Iberoamericana de Cultura y Pensamiento, n. ${ }^{\circ}$ 8, pp. 181-206. doi: 10.36008/monograma.2021.08.2146. http: revistamonograma.com. ISSN: 2603-5839. 
primera instancia la influencia de los medios de comunicación que recrea escenarios de violencia y delincuencia en zonas marginales, y expone por tanto al menor frente a procesos de exclusión social; y por otra parte, una estigmatización secundaria, en el que la condena social e institucional refuerza la autopercepción y el recrudecimiento de su violencia a través del tratamiento mediático, provocando una reacción social de aversión hacia los delincuentes.

La difusión social de una percepción tergiversada del menor infractor, criminaliza de manera especial a los adolescentes más vulnerables del contexto social; la concepción de un binomio entre menor marginado y peligrosidad, genera la expectativa de una sociedad que no espera que se produzca criminalidad de otros contextos separados a los del menor marginado y excluido, generando una posición de etiquetaje delincuencial; donde el menor asume el rol tachado por el ente social (Tsukame, 2016: 184, 188).

Esta conexión de fenómenos sobre los que recae la integración y participación del menor en las maras, se debe entender desde el estilo Durkheim, en el cual un hecho social a nivel macro (marginación y exclusión social), apela a otro hecho social a nivel macro (la reacción social como estigmatización) desencadenando en consecuencia la delincuencia. Se debe enfatizar sobre el poder de la opinión pública en la construcción social del miedo a través de los medios de comunicación, respecto a lo que es percibido como un riesgo para el orden social; y como recae en la demanda por implementar mecanismos de control social (Scheerer, 2016: 159).

Podríamos deducir que, si bien es cierto, esta teoría no explica por sí sola la delincuencia. Sin embargo, apela a como esta se suele reforzar o recrudecer en una sociedad ante la estigmatización, a través de diferentes agentes sociales; entre ellos los medios de

VÁsquez Hernández, Yaritza María (2021). «Terrorismo mediático: incidencia del tratamiento mediático en la imagen del menor pandillero en Honduras». Monograma. Revista Iberoamericana de Cultura y Pensamiento, n. ${ }^{\circ}$ 8, pp. 181-206. doi: 10.36008/monograma.2021.08.2146. http: revistamonograma.com. ISSN: 2603-5839. 
comunicación. Los cuales emiten notas que atentan contra su dignidad e intimidad, aún siendo menores o jóvenes, predisponiéndolos no solo a continuar con su trayectoria delincuencial, sino también a la incapacidad de reconciliarse con una sociedad.

El principal motivo de condena social para los menores es crecer y sobrevivir en una zona marginal controlada por las maras, desde donde son juzgados por la sociedad como vándalos y delincuentes, excluyéndolos de todas las formas de participación social, lo que a su vez genera conflictividades en el menor y lo empuja ha actuar conforme los señalamientos estigmatizadores, convirtiéndole en un blanco fácil para la reclutación y adoctrinamiento por parte de las maras y pandillas ${ }^{4}$.

\subsection{Los medios de comunicación como generadores de opinión pública}

Ante el panorama de una sociedad cada vez más globalizada, ha sido necesario consolidar el derecho la información, comprendiéndose no solo desde el ámbito individual, sino también desde el social; bajo las caracterizaciones de una información oportuna, amplia e imparcial. Sobre la verdad no solo se construyen realidades sociales, sino también la demanda y reivindicación de los derechos.

La primera obligación del periodista recae sobre el respeto y lealtad a la verdad, así como el derecho público a conocerla en virtud de una nota informativa. Por lo que el periodista está llamado en la obligación de encontrar en la veracidad el límite más inmediato de su profesión (Gavel Abella, 1999: 77). En este sen-

\footnotetext{
4 Las maras empiezan a reclutar a los menores con mayor intensidad, aprovechándose de las carencias sociales, económicas que se producen a causa de la exclusión social. Prometiendo el sentido de pertenencia a las maras, y una vida llena de placeres. Véase: https://www. laprensagrafica.com/internacional/Pandillas-y-crimen-organizado-aprovechan-vulnerabilidadpara-reclutar-a-ninos-en-pobreza-20180403-0062.html.
}

VÁsquez Hernández, Yaritza María (2021). «Terrorismo mediático: incidencia del tratamiento mediático en la imagen del menor pandillero en Honduras». Monograma. Revista Iberoamericana de Cultura y Pensamiento, n. ${ }^{\circ}$ 8, pp. 181-206. doi: 10.36008/monograma.2021.08.2146. http: revistamonograma.com. ISSN: 2603-5839. 
tido, el rol que desempeñan los medios de comunicación social y explícitamente el periodista que redacta y difunde sus notas es fundamental para comprender los hechos sociales; en los que fungen como intermediarios entre la fuente de información y el público como receptor.

Por lo que, una de las cuestiones que ha despertado interés y polémica a lo largo de los cambios sociales, ha sido el alcance de la influencia de los medios de comunicación; en la que se despliega su función social que atiende al plano moral y emocional. Tras el estudio de las diversas funciones sociales que desarrollan los medios de comunicación, y que se suelen centrar en el control social que ejercen o la formación de una conciencia, es preciso indagar sobre el efecto directo que involucra la emisión de sus contenidos. En relación con estas implicaciones, a lo largo de estudios realizados se ha derivado a la trascendencia de los medios de comunicación en su rol social como productor y difusor de estereotipos, o la incidencia en la violencia y delincuencia (Werder, 2009: 633).

Diversas teorías han contextualizado la trascendencia de los MCS. En primera instancia la teoría sobre los efectos de la comunicación persuasiva y aguja hipodérmica juegan un papel fundamental, en el que enfoca el papel del receptor como un sujeto vulnerable que reacciona de manera automática a la fuente de información; develando su vulnerabilidad basada en el modelo de estímulo-respuesta. Tal aseveración, ha sido afirmada tras el análisis del comportamiento de los receptores después de una noticia de impacto emocional como es el caos, desorden y terrorismo que han desencadenado un efecto contagioso, que recrea posteriormente un imaginario social (Terrero, 1998: 165). Y es que, para comprender la trascendencia de los medios de comunicación social, se debe partir de la idea que no se puede comunicar sin provocar alguna respuesta en el colectivo.

VÁsquez Hernández, Yaritza María (2021). «Terrorismo mediático: incidencia del tratamiento mediático en la imagen del menor pandillero en Honduras». Monograma. Revista Iberoamericana de Cultura y Pensamiento, n. ${ }^{\circ}$ 8, pp. 181-206. doi: 10.36008/monograma.2021.08.2146. http: revistamonograma.com. ISSN: 2603-5839. 
De allí la responsabilidad que conlleva informar con objetividad e imparcialidad. Respecto a la Teoría de la aguja hipodérmica se sugiere, que los MCS pueden manipular la opinión influyendo o «inyectando bajo la piel» de la audiencia un contenido que produzca una serie de reacciones u acciones determinadas; y es que el procesamiento de los mensajes por parte del receptor es irracional y sejemente e inmediato, debido a que la noticia se presenta de manera verosímil y confiable. Al comparar esta teoría con la cuestión que atañe al presente artículo, se puede vincular esta teoría con el efecto sensacionalista que se produce, respecto a la percepción de inseguridad ante la criminalidad del menor en las maras (Santaolalla, 2018: 78).

Es preciso señalar, que pese a la antigüedad y que a consideración de muchos teóricos las teorías de los efectos de la aguja hipodérmica y persuasión están obsoletas, y profundamente cuestionadas, su aplicación emerge aún y se ejemplifica en la campaña mediática contra las maras y pandillas en Honduras; como una realidad que no es ajena ante los efectos de los medios de comunicación que refuerzan la imagen del delincuente que interioriza el colectivo social.

Cabe señalar, que la opinión pública que se genera depende mayormente de los discursos dominantes que de la experiencia personal del individuo. Y es que, se debe hacer hincapié en que tanto la discusión pública y la divulgación sensacionalista tienen ubicuidad y un fuerte impacto en el colectivo social; y esto es debido, que a la medida que se refuerza el cuento mediático que recrean los medios de comunicación social, este adquiere no solo una mayor atención, sino la aprobación de su contenido. Por lo que, considerando los discursos mediáticos que se construyen en torno al imaginario social sobre el menor marero, los MCS no reproducen la realidad de manera objetiva; caso contrario, a tra-

VÁsquez Hernández, Yaritza María (2021). «Terrorismo mediático: incidencia del tratamiento mediático en la imagen del menor pandillero en Honduras». Monograma. Revista Iberoamericana de Cultura y Pensamiento, n. ${ }^{\circ}$ 8, pp. 181-206. doi: 10.36008/monograma.2021.08.2146. http: revistamonograma.com. ISSN: 2603-5839. 
vés del poder simbólico de su discurso influyen en la creación de una realidad determinada, la de la construcción social del miedo (Huhn, 2008: 153).

No obstante, al escudriñar las implicaciones de la persuasión se debe atender a la acción instrumental y racional que repliega dentro del cambio de opiniones; el resultado emergente de la teoría de la persuasión tiene un componente desestigmatizador respecto a los menores delincuentes, sí se utiliza como una estrategia pragmática para readaptar con un enfoque positivo la realidad de los menores que confluyen en zonas marginales y se encuentran en situación de riesgo social.

\subsection{Tratamiento mediático del menor pandillero}

Al contextualizar la situación de inseguridad en Honduras, se pone de manifiesto la lucha contra la delincuencia, la cual se extrapola principalmente a las maras cómo una de las mayores preocupaciones sociales en el tema de seguridad. Las políticas criminales represivas adoptadas por el gobierno, las cuales fueron el resultado de una mayor demanda social a causa del tratamiento mediático del tema de las maras, se encaminaron a incidir en reacciones sociales aversivas sobre los mareros, que empezaron a justificar las acciones del gobierno. Es bajo esa representación social supeditada al cuento mediático de los medios de comunicación, en donde surgen imaginarios sociales que penetran de manera inconsciente en la percepción de cada individuo, y refuerzan la etiqueta de delincuentes a los mareros y estereotipan a los menores que habiten en zonas dominadas por ellos.

Los medios de comunicación en general, y de manera más precisa los periódicos: La Prensa y El Heraldo promovieron una especie de cuento mediático, a partir de la figura del menor den-

VÁsquez Hernández, Yaritza María (2021). «Terrorismo mediático: incidencia del tratamiento mediático en la imagen del menor pandillero en Honduras». Monograma. Revista Iberoamericana de Cultura y Pensamiento, n. ${ }^{\circ}$ 8, pp. 181-206. doi: 10.36008/monograma.2021.08.2146. http: revistamonograma.com. ISSN: 2603-5839. 
tro de las maras, lo que genera alarmismo y promueve realidades distorsionadas sobre estos menores, y que no contribuyen en nada a la reconstrucción del tejido social; titulares como: «Maras y Pandillas entrenan niños para que se vuelvan más crueles con sus víctimas ${ }^{5}$; "Menores de edad, la Nueva cara de la pandilla» ${ }^{6}$ o «Pandillas utilizan a menores como verdugos en las casas locas» ${ }^{7}$, son algunos de los encabezados que han ocupado estos espacios informativos; lo que contribuye a destruir la reputación de estos niños, separándolos aún más de la sociedad. Es evidente la criminalización a la niñez e infancia de Honduras, en especial aquella que radica en barrios marginales.

Lo dicho hasta aquí supone, que los medios de comunicación tienen un papel relevante en la formación de opinión pública; y aunque no son los únicos responsables de la construcción social del miedo al delito, o la percepción de inseguridad, es indiscutible que, el lenguaje simbólico de sus discursos dirigidos a la población en general tiene un matiz que altera la realidad de los menores y demanda un mayor control social, a través de mecanismos más represivos ${ }^{8}$. De modo que, se debe concienciar a los medios de comunicación sobre su papel como agentes sociales de cambio, y escuelas de formación de opiniones, que contribuye

\footnotetext{
5 Esta nota informativa causó un efecto contagioso de alarma y temor social en las zonas periféricas de la ciudad. Véase: https://www.elheraldo.hn/pais/1154017-466/maras-y-pandillasentrenan-a-ni $\% \mathrm{C} 3 \% \mathrm{~B} 1$ os-para-que-se-vuelvan-crueles-con.

6 Son este tipo de titulares los que refuerzan la estigmatización hacia el sector de la niñez en Honduras y abogan por un tratamiento más severo, olvidando que el menor se encuentra en el desarrollo de su personalidad y autoconcepto: https://www.laprensa.hn/honduras/558232-97/ menores-de-edad-la-nueva-cara-de-las-pandillas.

7 Véase también: https://www.laprensa.hn/honduras/1086915-410/menores-pandillas-casas_ locas-maras-honduras-video-matan-asesinan-.

8 La demanda social por mayor seguridad provocó que desde la visión de los poderes ejecutivos y legislativos uno de los mecanismo de prevención de la delincuencia sería reducir la edad punible para someter a los menores al sistema de justicia de adultos: https://www.laprensa.hn/ honduras/1082315-410/edad_punible-menores-codigo-ni\%C3\%B1ez-rolando_argueta-juan_ orlando_hernandez.
}

VÁsquez Hernández, Yaritza María (2021). «Terrorismo mediático: incidencia del tratamiento mediático en la imagen del menor pandillero en Honduras». Monograma. Revista Iberoamericana de Cultura y Pensamiento, n. ${ }^{\circ}$ 8, pp. 181-206. doi: 10.36008/monograma.2021.08.2146. http: revistamonograma.com. ISSN: 2603-5839. 
a la visión que el individuo tiene de sí mismo, pero también de la sociedad; Facilitando la reconstrucción del tejido social con un enfoque positivo desde su alcance, que favorezca la reeducación e inclusión social de los menores que fueron reclutados y adoctrinados por las maras, por la única condena de residir en zonas donde establecían su legítimo poder (Guinsberg, 2005: 29).

\section{Conclusiones}

La percepción de inseguridad en torno a la participación del menor a las maras se refuerza a través de discursos mediáticos que alimentan el miedo, y promueven la desintegración social del menor en la sociedad, estigmatizando su imagen como delincuente. Favoreciendo, por tanto, al recrudecimiento de la violencia y delincuencia.

VÁsquez Hernández, Yaritza María (2021). «Terrorismo mediático: incidencia del tratamiento mediático en la imagen del menor pandillero en Honduras». Monograma. Revista Iberoamericana de Cultura y Pensamiento, n. ${ }^{\circ}$, pp. 181-206. doi: 10.36008/monograma.2021.08.2146. http: revistamonograma.com. ISSN: 2603-5839. 


\section{REFERENCIAS BIBLIOGRÁFICAS}

Abella, D. G. (1999). «Derecho a la información y medios de comunicación». Boletín de la $A N A B A D$, pp. 77-82.

Brandariz García, J. Á. (2007). «Sensación de riesgo y percepción de la inseguridad ante el delito. La función de los medios de comunicación y de las retóricas institucionales». En BRANdariz García, J. Á. Política Criminal de la Exclusión. Granada: Comares, pp. 65-79.

Contró, M. G. (2011). «¿Menores o niñas, niños y adolescentes? Reflexiones en el contexto del debate en América Latina». Publicación Electrónica (5), pp. 35-48.

FAzIO, C. (2013). «Terrorismo mediático: La construcción social del miedo en México». Revista Latinoaméricana de Comunicación (125), pp. 93-95.

FERnÁndeZ, F. (2008). «El asesinato del periodismo». En Encuentros Latinoamericanos vs. Terrorismo mediático. Caracas: Ministerio del Poder popular para la comunicación y la información, pp. 253-267.

Garrido-Genovés, V. (1986). Delincuencia Juvenil. Madrid: Alhambra.

GonzÁles, M. I. y Calderón, S. M. (2013). Teorías de la Criminalidad. Valencia: Tirant lo Blanch.

Guinsberg, E. (2005). Control de los medios, control del hombre: medios masivos y formación psicosocial. México: Plaza y Valdés.

Herrero, C. H. (2017). Criminología. Parte General y Especial. Madrid: Dykinson.

Huhn, S. (2008). «La percepción social de la inseguridad en Costa Rica, El Salvador y Nicaragua». Revista de Ciencias Sociales, vol. 4 (122), pp. 149-165.

LORETI, D. (1995). El Derecho a la Información. Relación entre medios, público y periodistas. Barcelona: Paidós.

VÁsquez Hernández, Yaritza María (2021). «Terrorismo mediático: incidencia del tratamiento mediático en la imagen del menor pandillero en Honduras». Monograma. Revista Iberoamericana de Cultura y Pensamiento, n. ${ }^{\circ}$ 8, pp. 181-206. doi: 10.36008/monograma.2021.08.2146. http: revistamonograma.com. ISSN: 2603-5839. 
Luckmann, P. L. y Berger, Th. (1968). La construcción social de la realidad. Buenos Aires: Amorrortu.

Martínez, P. G. (2008). Las maras al Desnudo. Málaga: SEPHA.

Maz, M. F. (2010). «El tratamiento informativo de los grupos socialmente desfavorecidos». En Single, C., Clavera, S. A. y SALGADO, F. La ética informativa vista por los ciudadanos: contraste de opiniones entre los periodistas y el público. Barcelona: UOC, pp. 87-106.

Maza, F. X. y Alonso, J. D. (2017). «Vinculación entre la vulnerabilidad y exclusión social y las trayectorias delictivas. Un estudio de asociación». Psychosocial Intervention, 26(1), pp. 29-37.

MendozA, B. (27 de Noviembre de 2017). La MS-13 le «entrega almas al diablo»: el trasfondo satánico de esta pandilla, según The Washington Post. Disponible en: https://www.laprensagrafica.com/elsalvador/La-MS-13-le-entrega-almas-al-diablo-eltrasfondo-satanico-de-esta-pandilla-segun-The-WashingtonPost-20171227-0057.html.

Navarro, S. S. (2005). «La delincuencia en la agenda mediática». Revista Española de Investigaciones Sociológicas, pp. 75-130.

Rodríguez, P. (1985). Las sectas hoy y aquí. Barcelona: Tibidabo.

Rutter, M. y Giller, H. (1983). Delincuencia Juvenil. Barcelona: Martínez Roca.

Santaolalla, V. H. (2018). Los efectos de los medios de comunicación de masas. Barcelona: UOC.

Scheerer, S. (2016). Derecho penal y Control social. Buenos Aires: Ad-Hoc.

Terrero, J. M. (1998). «El impacto moral y social de los medios de comunicación social». Comunicar (10), pp. 164-170.

Tsukame, A. S. (2016). «El rol de los medios de comunicación en la construcción de discursos en la guerra contra la delincuencia juvenil en Chile (1990-2016)». Polis, pp. 181-201.

VArona, D. (2011). «Medios de comunicación y Punitivismo». Revista para el análisis del Derecho, 1, pp. 1-34.

VÁsquez Hernández, Yaritza María (2021). «Terrorismo mediático: incidencia del tratamiento mediático en la imagen del menor pandillero en Honduras». Monograma. Revista Iberoamericana de Cultura y Pensamiento, n. ${ }^{\circ}$ 8, pp. 181-206. doi: 10.36008/monograma.2021.08.2146. http: revistamonograma.com. ISSN: 2603-5839. 
Werder, O. H. (2009). «Media Effects Theories». En LittLejohn, S. W. y Foss, K. A. Encyclopedia of Communication Theory. Thousand Oaks: SAGE, pp. 633-635.

\section{Anexo Legislativo}

Convención sobre los Derechos del Niño, 20 de noviembre de 1989, Naciones Unidas.

Código Penal de Honduras, Decreto número 130-2017, La Gaceta, 10 de mayo de 2019.

Código de la Niñez y Adolescencia, Decreto número 73-96, La Gaceta, 31 de mayo 1996.

VÁsquez HernándeZ, Yaritza María (2021). «Terrorismo mediático: incidencia del tratamiento mediático en la imagen del menor pandillero en Honduras». Monograma. Revista Iberoamericana de Cultura y Pensamiento, n. ${ }^{\circ}$ 8, pp. 181-206. doi: 10.36008/monograma.2021.08.2146. http: revistamonograma.com. ISSN: 2603-5839. 